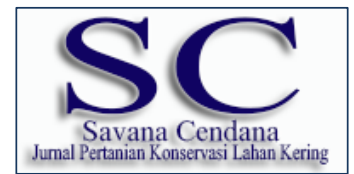

\title{
Pengaruh Takaran Guano dan Konsentrasi Teh Kompos terhadap Pertumbuhan dan Hasil Kacang Hijau (Vigna radiata, L.)
}

Eduardus Yosef Neonbeni ${ }^{\mathrm{a}}$ dan Ambrosius Seran ${ }^{\mathrm{b}}$

${ }^{a}$ Fakultas Pertanian, Universitas Timor, Kefamenanu, TTU - NTT, Indonesia.

${ }^{\mathrm{b}}$ Fakultas Pertanian, Universitas Timor, Kefamenanu, TTU - NTT, Indonesia.

\section{Article Info}

\section{Article history:}

Received 19 Mei 2017

Received in revised form 1 Juni 2017

Accepted 25 Juni 2017

\section{Keywords:}

Guano

Kacang Hijau

Teh Kompos

\begin{abstract}
Abstrak
Penelitian ini bertujuan untuk mendapatkan takaran guano dan konsentrasi teh kompos yang memberikan pertumbuhan dan hasil yang tertinggi bagi kacang hijau (Vigna radiata, L.) varietas unggul lokal Fore Belu. Guano 0 t/ha, 1 t/ha, 2 t/ha dan 3 t/ha sebagai pupuk akar diberikan yang dikombinasikan dengan teh kompos konsentrasi 1:5 (bokasi $1 \mathrm{~kg}$ diekstrak dengan 5 liter air) dan 1:10 (bokasi $1 \mathrm{~kg}$ diekstrak dengan 10 liter air) yang disemprotkan melalui daun. Perlakukan disusun menurut Rancangan Acak kelompok faktorial yang diulang dalam empat blok. Teh kompos diberikankan melalui daun dan akar setiap minggu semenjak kacang hijau berumur 14 hari hingga 42 hari setelah tanam. Hasil penelitian menunjukkan bahwa parameter pertumbuhan (diameter batang, panjang akar, luas daun) dan hasil kacang hijau (berat biji kering) tertinggi diperoleh dari pemberian guano $2 \mathrm{t} / \mathrm{ha}$. Pemberian teh kompos konsentrasi 1:5 secara signifikan menurunkan serangan karat daun yang mengindikasikan adanya peningkatan ketahanan kacang hijau terhadap penyakit. (C)2017 dipublikasikan oleh Savana Cendana.
\end{abstract}

\section{Pendahuluan}

Kacang hijau (Vigna radiata, L.) merupakan salah satu komoditas tanaman kacang-kacangan yang diusahakan selain untuk memperoleh produknya sebagai bahan pangan (bijinya), juga untuk tujuan memperbaiki kesuburan tanah melalui penambatan nitrogen dari udara (Yugi \& Harjoso, 2012). Produktivitas kacang hijau secara umum meningkat, namun di Kabupaten TTU produktivitas tersebut berfluktuasi. Pada 2012 produktivitas kacang hijau di TTU mencapai 9,4 t/ha akan tetapi semenjak tahun 2013 hingga 2014 menurun dari 9,00 hingga 8,93 t/ha (BPS Kab. TTU, 2015) Penurunan produktivitas tersebut mengindikasikan menurunnya produktivitas tanah disamping faktor gangguan seperti penyakit karat atau bercak daun. Fore Belu, salah satu varietas unggul lokal kacang hijau di NTT termasuk tahan terhadap kekeringan dan penyakit karat daun, namun pada tingkat serangan yang berat dapat menyebabkan penurunan luas daun sehingga menurunkan hasil.

Guano, berdasarkan hasil penelitian terdahulu, mampu memperbaiki produktivitas tanah, antara lain melalui peningkatan kapasitas tanah mengikat air, memperbaiki bobot volume tanah, meningkatkan kemampuan tanah mengikat hara, dan menjadi sumber hara tanaman. Penelitian (Taek, 2016) dengan pemberian biochar sekam padi 5 t/ha yang dikombinasikan dengan guano $5 \mathrm{t} /$ ha dapat meningkatkan hasil kacang hijau.

Teh kompos atau ekstrak kompos, selain menyuburkan tanah, dapat juga digunakan sebagai pestisida organik karena mikroba yang terkandung didalamnya dapat berfungsi sebagai antagonis penyebab penyakit karat daun. Teh kompos juga dapat menambah substansi humus, hormon tumbuh dan enzim serta senyawa-senyawa organik lainnya di dalam tanah (Nadiah, 2012). Teh kompos telah terbukti berpengaruh positif pada beberapa komoditi pertanian. Penelitian (Bria, 2016) membuktikan bahwa jenis dan konsentrasi teh kompos berpengaruh terhadap pertumbuhan dan hasil bayam merah.

Pemberian guano takaran tinggi (2 t/ha) pada kacang hijau dapat meningkatkan hasil. Namun, dengan kandungan hara $(\mathrm{N})$ yang tinggi jika diaplikasikan pada kacang-kacangan, dapat menghambat proses fiksasi $\mathrm{N}$ oleh karena itu, tujuan dari penelitian ini adalah mendapatkan takaran guano yang lebih rendah yang dapat memberikan hasil kacang yang tinggi dan konsentrasi teh kompos optimum yang dapat menekan serangan penyakit bercak atau karat daun kacang hijau varietas unggul lokal Fore Belu.

\section{Metode}

Penelitian dilaksanakan di kampus Universitas Timor, Kelurahan Sasi, Kecamatan Kota Kefamenanu, Kabupaten TTU pada bulan sampai April sampai Juni 2017. Kombinasi takaran guano dan konsentrasi teh kompos disusun dalam rancangan acak kelompok (RAK) faktorial 3 x 4 dengan 4 ulangan. Faktor pertama adalah takaran guano $(\mathrm{G})$ yang terdiri dari 4 aras yakni control/tanpa guano $\left(\mathrm{g}_{0}\right)$, guano $1 \mathrm{t} / \mathrm{ha}\left(\mathrm{g}_{1}\right)$, guano $2 \mathrm{t} / \mathrm{ha}\left(\mathrm{g}_{2}\right)$ dan guano $3 \mathrm{t} / \mathrm{ha}$ $\left(\mathrm{g}_{3}\right)$. Faktor kedua adalah konsentrasi teh kompos yang terdiri dari tiga aras, yaitu: control/tanpa teh kompos $\left(\mathrm{k}_{0}\right)$, teh kompos 1:5 $\left(\mathrm{k}_{1}\right)$, dan teh kompos 1:10 $\left(\mathrm{k}_{2}\right)$. Kombinasi perlakuannya adalah: $\mathrm{k}_{0} \mathrm{~g}_{0}, \mathrm{k}_{0} \mathrm{~g}_{1}, \mathrm{k}_{0} \mathrm{~g}_{2}, \mathrm{k}_{0} \mathrm{~g}_{3}, \mathrm{k}_{5} \mathrm{~g}_{0}, \mathrm{k}_{5} \mathrm{~g}_{1}, \mathrm{k}_{5} \mathrm{~g}_{2}$, $\mathrm{k}_{5} \mathrm{~g}_{3}, \mathrm{k}_{10} \mathrm{~g}_{0}, \mathrm{k}_{10} \mathrm{~g}_{1}, \mathrm{k}_{10} \mathrm{~g}_{2}, \mathrm{k}_{10} \mathrm{~g}_{3}$.

Lahan percobaan merupakan lahan baru yang ditumbuhi rumput alami. Lahan dipersiapkan dengan membersihkan rumput, dibalik menggunakan traktor, diikuti pembuatan bedeng dengan ukuran 2,10 x 1,60 $\mathrm{m}^{2}$ serta diberi label sesuai perlakuan. Guano diperoleh dari Eban dikeringkan, diayak dan ditimbang. Total pupuk yang digunakan adalah: kontrol $0 \mathrm{t} / \mathrm{ha}$ setara dengan 0 $\mathrm{kg} /$ petak, $1 \mathrm{t} / \mathrm{ha}$ setara dengan $336 \mathrm{gr} /$ petak, $2 \mathrm{t} / \mathrm{ha}$ setara dengan $672 \mathrm{gr} /$ petak dan $3 \mathrm{t} /$ ha setara dengan 1,008 g, per bedeng sesuai perlakukan. Benih kacang hijau diperoleh dari petani di Kabupaten Malaka, disortir dan ditanam 4 biji per lubang dengan jarak tanam $25 \mathrm{~cm}$ x $40 \mathrm{~cm}$. Penyiraman dilakukan setiap hari 2 kali. Penyiangan dilakukan 3 kali pada saat tanman berumur 7 hari setelah tanam dan 32 hari setelah tanam Pengendalian hama dan penyakiti disesuaikan dilapangan, dengan kriteria panen adalah Sewaktu kacang hijau tua dan buahnya berwarna hitam atau coklat.
Pengamatan dilakukan terhadap suhu, $\mathrm{pH}$ dan DHL tanah, tinggi tanaman, jumlah daun, luas daun, luas daun, bercak/karat daun, jumlah bintil akar, berat segar tanaman, berat kering tanaman, jumlah polong, panjang polong, jumlah biji per polong, berat biji per tanaman, berat biji/polong (t/ha), berat seratus biji, berat segar berangkasan, berat kering berangkasan, dan Indeks panen (\%)

Data hasil pengamatan kemudian dianalisis dengan menggunakan sidik ragam (Anova) Rancangan Acak Kelompok (RAK). Rata-rata perlakuan selanjutnya diuji lanjut dengan menggunakan Duncan Multiple Range Test (DMRT) dengan tingkat signifikan 5\% sesuai petunjuk (Gomez \& Gomez, 1984). Analisis data menggunakan program SAS 9.1

\section{Hasil dan Pembahasan}

\subsection{Suhu tanah}

Hasil sidik ragam (Anova) menunjukkan bahwa ada interaksi antara pemberian guano dan pengaplikasian teh kompos pada suhu tanah setiap waktu pengamatan, namun pada akhir pengamatan pemberian guano 2 t/ha suhu tanahnya lebih rendah dari pada $1 \mathrm{t} / \mathrm{ha}, 3 \mathrm{t} / \mathrm{ha}$ dan kontrol.

\section{Tabel 1. Suhu Tanah}

\begin{tabular}{|c|c|c|c|c|c|}
\hline \multirow{2}{*}{$\begin{array}{c}\text { Waktu } \\
\text { Pengamatan }\end{array}$} & \multirow{2}{*}{$\begin{array}{c}\text { Takaran } \\
\text { Guano }\end{array}$} & \multicolumn{3}{|c|}{ Konsentrasi Teh Kompos } & \multirow{2}{*}{ Rerata } \\
\hline & & Kontrol & $1: 5$ & $1: 10$ & \\
\hline \multirow{5}{*}{14 HST } & Kontrol & 34.50 & 34.24 & 35.57 & $34.77 \mathrm{a}$ \\
\hline & $1 \mathrm{t} / \mathrm{ha}$ & 35.33 & 34.42 & 34.39 & $34.71 \mathrm{a}$ \\
\hline & $2 \mathrm{t} / \mathrm{ha}$ & 34.77 & 34.26 & 34.78 & $34.60 \mathrm{a}$ \\
\hline & $3 \mathrm{t} / \mathrm{ha}$ & 34.13 & 34.99 & 34.37 & $34.50 \mathrm{a}$ \\
\hline & Rerata & $34.68 \mathrm{a}$ & $34.48 \mathrm{a}$ & $34.78 \mathrm{a}$ & $(-)$ \\
\hline \multirow{5}{*}{$28 \mathrm{HST}$} & Kontrol & $28.18 \mathrm{~b}$ & $28.00 \mathrm{a}$ & $28.37 \mathrm{~b}$ & 28.18 \\
\hline & $1 \mathrm{t} / \mathrm{ha}$ & $28.21 \mathrm{a}$ & $28.49 \mathrm{~b}$ & $28.43 \mathrm{~b}$ & 28.38 \\
\hline & $2 \mathrm{t} / \mathrm{ha}$ & $28.33 \mathrm{~b}$ & $30.67 \mathrm{~b}$ & $30.34 \mathrm{a}$ & 29.78 \\
\hline & $3 \mathrm{t} / \mathrm{ha}$ & $30.48 \mathrm{a}$ & $30.62 \mathrm{a}$ & $31.06 \mathrm{a}$ & 30.72 \\
\hline & Rerata & 28.80 & 29.44 & 29.55 & $(+)$ \\
\hline \multirow{5}{*}{$42 \mathrm{HST}$} & Kontrol & $32.62 \mathrm{ab}$ & $32.73 \mathrm{ab}$ & $32.97 \mathrm{ab}$ & 32.77 \\
\hline & $1 \mathrm{t} / \mathrm{ha}$ & $32.49 \mathrm{ab}$ & $33.53 \mathrm{a}$ & $31.78 \mathrm{ab}$ & 32.60 \\
\hline & $2 \mathrm{t} / \mathrm{ha}$ & $32.10 \mathrm{ab}$ & $30.73 b$ & $31.93 \mathrm{ab}$ & 31.59 \\
\hline & $3 \mathrm{t} / \mathrm{ha}$ & $31.98 \mathrm{ab}$ & $31.63 \mathrm{ab}$ & $33.23 \mathrm{a}$ & 32.28 \\
\hline & Rerata & 32.30 & 32.16 & 32.48 & $(+)$ \\
\hline
\end{tabular}
pada tingkat $\alpha 5 \%$ menurut uji DMRT. (+): Terjadi interaksi antar faktor.

\section{2 pH tanah}

Hasil sidik ragam (Anova) menunjukkan bahwa rata-rata $\mathrm{pH}$ tanah tidak nyata dipengaruhi baik interaksi maupun masing-masing faktor. Data Tabel 2. menunjukkan bahwa penggunaan guano 1 t/ha $\mathrm{pH}$-nya lebih rendah dibandingkan $2 \mathrm{t} / \mathrm{ha}, 3 \mathrm{t} / \mathrm{ha}$ dan kontrol. Sedangkan penggunaan teh kompos 1:5 dan 1:10 pH-nya sama dibandingkan dengan Kontrol.

\section{Tabel 2. pH Tanah}

\begin{tabular}{ccccc}
\hline \multirow{2}{*}{ Takaran Guano } & \multicolumn{3}{c}{ Konsentrasi Teh Kompos } & \multirow{2}{*}{ Rerata } \\
\cline { 2 - 4 } & Kontrol & $1: 5$ & $1: 10$ & \\
\hline Kontrol & 7.43 & 7.39 & 7.45 & $7.42 \mathrm{a}$ \\
$1 \mathrm{t} / \mathrm{ha}$ & 7.43 & 7.31 & 7.30 & $7.34 \mathrm{a}$ \\
$2 \mathrm{t} / \mathrm{ha}$ & 7.34 & 7.37 & 7.36 & $7.36 \mathrm{a}$ \\
$3 \mathrm{t} / \mathrm{ha}$ & 7.44 & 7.39 & 7.35 & $7.39 \mathrm{a}$ \\
\hline Rerata & $7.41 \mathrm{a}$ & $7.37 \mathrm{a}$ & $7.37 \mathrm{a}$ & $(-)$ \\
\hline Keterangan: Angka pada kolom dan baris diikuti huruf sama menunjukkan tidak berbeda nyata
\end{tabular}

Keterangan: Angka pada kolom dan baris diikuti huruf sama menunjukkan tidak berbeda nyata pada tingkat $\alpha 5 \%$ menurut uji DMRT. (-): Tidak terjadi interaksi antar faktor.

\subsection{DHL tanah}

Hasil sidik ragam (Anova) menunjukkan bahwa DHL tanah nyata dipengaruhi baik interaksi maupun masing-masing faktor. Data Tabel 3. 
menunjukkan bahwa pemberian guano $2 \mathrm{t} / \mathrm{ha}$ meningkatkan daya hantar listirik berbeda nyata dengan pemberian guano $1 \mathrm{t} / \mathrm{ha}, 3$ t/ha dan kontrol.

Tabel 3. DHL Tanah

\begin{tabular}{cllll}
\hline \multirow{2}{*}{ Takaran Guano } & \multicolumn{3}{c}{ Konsentrasi Teh Kompos } & \multirow{2}{*}{ Rerata } \\
\cline { 2 - 4 } & \multicolumn{1}{|c}{ Kontrol } & \multicolumn{1}{c}{$1: 5$} & $1: 10$ & \\
\hline Kontrol & $374.75 \mathrm{abc}$ & $546.50 \mathrm{abc}$ & $558.75 \mathrm{abc}$ & 493.33 \\
$1 \mathrm{t} / \mathrm{ha}$ & $813.50 \mathrm{ab}$ & $494.25 \mathrm{abc}$ & $844.75 \mathrm{a}$ & 717.50 \\
$2 \mathrm{t} / \mathrm{ha}$ & $653.75 \mathrm{abc}$ & $706.75 \mathrm{abc}$ & $759.50 \mathrm{abc}$ & 706.67 \\
$3 \mathrm{t} / \mathrm{ha}$ & $561.75 \mathrm{abc}$ & $324.50 \mathrm{bc}$ & $341.00 \mathrm{bc}$ & 409.08 \\
\hline Rerata & 600.94 & 518.00 & 626.00 & $(+)$ \\
\hline
\end{tabular}

Keterangan: Angka pada kolom dan baris diikuti huruf sama menunjukkan tidak berbeda nyata pada tingkat $\alpha 5 \%$ menurut uji DMRT. (+): Terjadi interaksi antar faktor.

\subsection{Tinggi Tanaman}

Hasil sidik ragam (Anova) menunjukkan bahwa ada interaksi antara pemberian takaran guano dan konsentrasi teh kompos untuk tanaman kacang hijau pada setiap kali pengamatan. Data Tabel 4. menunjukkan bahwa dengan pemberian guano $2 \mathrm{t} / \mathrm{ha}$ yang tertinggi dibandingkan dengan $1 \mathrm{t} / \mathrm{ha}, 3 \mathrm{t} / \mathrm{ha}$ dan kontrol.

Tabel 4. Tinggi tanaman

\begin{tabular}{cccccc}
\hline Waktu & Takaran & \multicolumn{3}{c}{ Konsentrasi Teh Kompos } & \multirow{2}{*}{ Rerata } \\
\cline { 3 - 5 } Pengamatan & Guano & Kontrol & 1.5 & $1: 10$ & \\
\hline \multirow{4}{*}{$14 \mathrm{HST}$} & Kontrol & $9.94 \mathrm{abc}$ & $10.01 \mathrm{abc}$ & $10.21 \mathrm{abc}$ & 10.05 \\
& $1 \mathrm{t} / \mathrm{ha}$ & $10.08 \mathrm{abc}$ & $10.46 \mathrm{ab}$ & $9.47 \mathrm{c}$ & 10.00 \\
& $2 \mathrm{t} / \mathrm{ha}$ & $10.62 \mathrm{a}$ & $10.51 \mathrm{ab}$ & $9.96 \mathrm{abc}$ & 10.36 \\
& $3 \mathrm{t} / \mathrm{ha}$ & $9.57 \mathrm{abc}$ & $10.02 \mathrm{abc}$ & $10.09 \mathrm{bc}$ & 9.89 \\
\cline { 2 - 5 } & Rerata & 10.05 & 10.25 & 9.93 & $(-)$ \\
\hline \multirow{3}{*}{$28 \mathrm{HST}$} & Kontrol & $13.58 \mathrm{~b}$ & $13.20 \mathrm{ab}$ & $14.99 \mathrm{~b}$ & 13.92 \\
& $1 \mathrm{t} / \mathrm{ha}$ & $13.96 \mathrm{ab}$ & $14.70 \mathrm{ab}$ & $13.88 \mathrm{~b}$ & 14.18 \\
& $2 \mathrm{t} / \mathrm{ha}$ & $14.79 \mathrm{ab}$ & $15.84 \mathrm{a}$ & $14.59 \mathrm{ab}$ & 15.07 \\
& $3 \mathrm{t} / \mathrm{ha}$ & $13.38 \mathrm{ab}$ & $14.06 \mathrm{ab}$ & $14.54 \mathrm{ab}$ & 13.99 \\
\cline { 2 - 5 } & Rerata & 13.93 & 14.45 & 14.50 & $(+)$ \\
\hline \multirow{5}{*}{ K2 HST } & Kontrol & $17.61 \mathrm{ab}$ & $17.03 \mathrm{ab}$ & $20.26 \mathrm{ab}$ & 18.30 \\
& $1 \mathrm{t} / \mathrm{ha}$ & $19.03 \mathrm{a}$ & $19.14 \mathrm{a}$ & $18.35 \mathrm{ab}$ & 18.84 \\
& $2 \mathrm{t} / \mathrm{ha}$ & $20.20 \mathrm{ab}$ & $20.46 \mathrm{a}$ & $17.22 \mathrm{ab}$ & 19.29 \\
& $3 \mathrm{t} / \mathrm{ha}$ & $14.79 \mathrm{~b}$ & $18.35 \mathrm{ab}$ & $19.01 \mathrm{ab}$ & 17.38 \\
\cline { 2 - 5 } & Rerata & 17.91 & 18.74 & 18.71 & $(-)$ \\
\hline
\end{tabular}

Keterangan: Angka pada kolom dan baris diikuti huruf sama menunjukkan tidak berbeda nyata pada tingkat $\alpha .5 \%$ menurut uji DMRT. (+): Terjadi interaksi antar faktor.

\subsection{Panjang Akar}

Hasil sidik ragam (Anova) menunjukkan bahwa tidak ada interaksi antara pemberian takaran guano dan konsentrasi teh kompos untuk tanaman kacang hijau pada pengamatan panjang akar, namun pemberian takaran guano 2 t/ha menunjukkan beda nyata dibanding takaran $1 \mathrm{t} / \mathrm{ha}, 3 \mathrm{t} / \mathrm{ha}$ dan kontrol.

Tabel 5. Panjang Akar (cm)

\begin{tabular}{ccccc}
\hline \multirow{2}{*}{ Takaran Guano } & \multicolumn{3}{c}{ Konsentrasi Teh Kompos } & \multirow{2}{*}{ Rerata } \\
\cline { 2 - 4 } & Kontrol & $1: 5$ & $1: 10$ & \\
\hline Kontrol & 23.44 & 17.44 & 16.56 & $19.15 \mathrm{a}$ \\
$1 \mathrm{t} / \mathrm{ha}$ & 16.81 & 17.44 & 17.75 & $17.33 \mathrm{a}$ \\
$2 \mathrm{t} / \mathrm{ha}$ & 18.88 & 16.25 & 16.81 & $17.31 \mathrm{a}$ \\
$3 \mathrm{t} / \mathrm{ha}$ & 18.34 & 19.00 & 15.81 & $17.72 \mathrm{a}$ \\
\hline Rerata & $19.37 \mathrm{a}$ & $17.53 \mathrm{a}$ & $16.73 \mathrm{a}$ & $(-)$ \\
\hline
\end{tabular}

Keterangan: Angka pada kolom dan baris diikuti huruf sama menunjukkan tidak berbeda nyata pada tingkat $\alpha 5 \%$ menurut uji DMRT. (-): Tidak terjadi interaksi antar faktor.

Demikian pemberian teh kompos tidak memberikan pengaruh yang nyata namun pada konsentrasi 1:5 memiliki akar terpendek karena kondisi lingkungan tumbuh mendukung dimana unsur hara tersedia dibanding 1:10 dan kontrol.

\subsection{Diameter Batang}

Hasil sidik ragam (Anova) menunjukkan bahwa tidak ada interaksi antara pemberian takaran guano dan konsentrasi teh kompos untuk tanaman kacang hijau, namun pemberian takaran guano 2 t/ha batangnya jauh lebih besar dibanding takaran $1 \mathrm{t} / \mathrm{ha}, 3 \mathrm{t} / \mathrm{ha}$ dan kontrol. Demikian pemberian teh kompos tidak memberikan pengaruh yang nyata namun pada konsentrasi 1:10 meningkatkan diameter batang dibanding 1:5 dan kontrol.
Tabel 6. Diameter Batang $(\mathrm{cm})$

\begin{tabular}{|c|c|c|c|c|c|}
\hline \multirow{2}{*}{$\begin{array}{c}\text { Waktu } \\
\text { Pengamatan }\end{array}$} & \multirow{2}{*}{$\begin{array}{c}\text { Takaran } \\
\text { Guano }\end{array}$} & \multicolumn{3}{|c|}{ Konsentrasi Teh Kompos } & \multirow{2}{*}{ Rerata } \\
\hline & & Kontrol & $1: 5$ & $1: 10$ & \\
\hline \multirow{5}{*}{14 HST } & Kontrol & $0.24 \mathrm{~b}$ & $0.24 \mathrm{~b}$ & $0.24 \mathrm{~b}$ & 0.24 \\
\hline & $1 \mathrm{t} / \mathrm{ha}$ & $0.24 \mathrm{~b}$ & $0.24 \mathrm{a}$ & $0.24 \mathrm{~b}$ & 0.24 \\
\hline & $2 \mathrm{t} / \mathrm{ha}$ & $0.32 \mathrm{~b}$ & $0.85 \mathrm{~b}$ & $0.24 \mathrm{~b}$ & 0.47 \\
\hline & $3 \mathrm{t} / \mathrm{ha}$ & $0.24 \mathrm{~b}$ & $0.24 \mathrm{~b}$ & $0.24 \mathrm{~b}$ & 0.24 \\
\hline & Rerata & 0.26 & 0.39 & 0.24 & $(+)$ \\
\hline \multirow{5}{*}{$28 \mathrm{HST}$} & Kontrol & 0.30 & 0.32 & 0.36 & $0.33 \mathrm{a}$ \\
\hline & $1 \mathrm{t} / \mathrm{ha}$ & 0.33 & 0.31 & 0.33 & $0.32 \mathrm{a}$ \\
\hline & $2 \mathrm{t} / \mathrm{ha}$ & 0.36 & 0.35 & 0.34 & $0.35 \mathrm{a}$ \\
\hline & $3 \mathrm{t} / \mathrm{ha}$ & 0.33 & 0.33 & 0.33 & $0.33 \mathrm{a}$ \\
\hline & Rerata & $0.33 \mathrm{a}$ & $0.33 \mathrm{a}$ & $0.34 \mathrm{a}$ & $(-)$ \\
\hline \multirow{5}{*}{$42 \mathrm{HST}$} & Kontrol & 0.36 & 0.35 & 0.40 & $0.37 \mathrm{a}$ \\
\hline & $1 \mathrm{t} / \mathrm{ha}$ & 0.38 & 0.37 & 0.36 & $0.37 \mathrm{a}$ \\
\hline & $2 \mathrm{t} / \mathrm{ha}$ & 0.38 & 0.39 & 0.39 & $0.39 \mathrm{a}$ \\
\hline & $3 \mathrm{t} / \mathrm{ha}$ & 0.36 & 0.38 & 0.39 & $0.37 \mathrm{a}$ \\
\hline & Rerata & $0.37 \mathrm{a}$ & $0.37 \mathrm{a}$ & $0.39 \mathrm{a}$ & $(-)$ \\
\hline
\end{tabular}

Keterangan: Angka pada kolom dan baris diikuti huruf sama menunjukkan tidak berbeda nyata pada tingkat $\alpha 5 \%$ menurut uji DMRT. (+): Terjadi interaksi antar faktor.

\subsection{Jumlah Daun}

Hasil sidik ragam (Anova) menunjukkan bahwa tidak ada interaksi antara pemberian takaran guano dan konsentrasi teh kompos untuk tanaman kacang hijau pada pengamatan 14,28 dan 42 HST, namun pemberian takaran guano 3 t/ha pada pengamatan 42 HST menunjukkan beda nyata dibanding takaran 1 $\mathrm{t} / \mathrm{ha}, 2 \mathrm{t} / \mathrm{ha}$ dan kontrol. namun pemberian teh kompos 1:10 memberikan pengaruh yang nyata pada 14 HST dibandingkan konsentrasi 1: 5 dan kontrol.

Tabel 7. Jumlah Daun

\begin{tabular}{|c|c|c|c|c|c|}
\hline \multirow{2}{*}{$\begin{array}{c}\text { Waktu } \\
\text { Pengamatan }\end{array}$} & \multirow{2}{*}{$\begin{array}{c}\text { Takaran } \\
\text { Guano }\end{array}$} & \multicolumn{3}{|c|}{ Konsentrasi Teh Kompos } & \multirow{2}{*}{ Rerata } \\
\hline & & Kontrol & $1: 5$ & $1: 10$ & \\
\hline \multirow{5}{*}{14 HST } & Kontrol & $4.98 \mathrm{~b}$ & $5.05 \mathrm{~b}$ & $5.38 \mathrm{ab}$ & 5.13 \\
\hline & $1 \mathrm{t} / \mathrm{ha}$ & $5.08 \mathrm{ab}$ & $5.08 \mathrm{ab}$ & $5.30 \mathrm{ab}$ & 5.15 \\
\hline & $2 \mathrm{t} / \mathrm{ha}$ & $4.98 \mathrm{~b}$ & $5.63 \mathrm{a}$ & $5.35 \mathrm{ab}$ & 5.32 \\
\hline & $3 \mathrm{t} / \mathrm{ha}$ & $5.13 \mathrm{ab}$ & $5.08 \mathrm{ab}$ & $5.20 \mathrm{ab}$ & 5.13 \\
\hline & Rerata & 5.04 & 5.21 & 5.31 & $(+)$ \\
\hline \multirow{5}{*}{$28 \mathrm{HST}$} & Kontrol & $9.93 \mathrm{~b}$ & $10.13 \mathrm{~b}$ & $11.68 \mathrm{ab}$ & 10.58 \\
\hline & $1 \mathrm{t} / \mathrm{ha}$ & $11.50 \mathrm{ab}$ & $11.15 \mathrm{ab}$ & $11.53 \mathrm{ab}$ & 11.39 \\
\hline & $2 \mathrm{t} / \mathrm{ha}$ & $11.18 \mathrm{ab}$ & $12.38 \mathrm{a}$ & $11.45 \mathrm{ab}$ & 11.67 \\
\hline & 3 t/ha & $10.43 \mathrm{ab}$ & $10.85 \mathrm{ab}$ & $11.90 \mathrm{ab}$ & 11.06 \\
\hline & Rerata & 10.76 & 11.13 & 11.64 & $(+)$ \\
\hline \multirow{5}{*}{$42 \mathrm{HST}$} & Kontrol & 14.20 & 14.50 & 16.03 & $14.91 \mathrm{a}$ \\
\hline & $1 \mathrm{t} / \mathrm{ha}$ & 15.30 & 15.50 & 16.30 & $15.70 \mathrm{a}$ \\
\hline & $2 \mathrm{t} / \mathrm{ha}$ & 14.75 & 16.13 & 14.33 & $15.07 \mathrm{a}$ \\
\hline & $3 \mathrm{t} / \mathrm{ha}$ & 14.30 & 14.73 & 15.75 & $14.93 \mathrm{a}$ \\
\hline & Rerata & $14.64 \mathrm{a}$ & $15.21 \mathrm{a}$ & $15.60 \mathrm{a}$ & $(-)$ \\
\hline
\end{tabular}
pada tingkat $\alpha 5 \%$ menurut uji DMRT. (+): Terjadi interaksi antar faktor.

\subsection{Luas Daun}

Hasil sidik ragam (Anova) menunjukkan bahwa tidak ada interaksi antara pemberian takaran guano dan konsentrasi teh kompos untuk tanaman kacang hijau pada pengamatan luas daun, namun pemberian takaran guano 2 t/ha menunjukkan beda nyata dibanding takaran 1 t/ha, 3 t/ha dan kontrol. demikian pemberian teh kompos tidak memberikan pengaruh yang nyata namun pada konsentrasi 1:5 meningkatkan luas daun dibanding 1:10 dan kontrol.

\section{Tabel 8. Luas Daun}

\begin{tabular}{ccccc}
\hline \multirow{2}{*}{ Takaran Guano } & \multicolumn{3}{c}{ Konsentrasi Teh Kompos } & \multirow{2}{*}{ Rerata } \\
\cline { 2 - 4 } & Kontrol & $1: 5$ & $1: 10$ & \\
\hline Kontrol & 7.290 & 5.342 & 5.118 & $5.917 \mathrm{a}$ \\
$1 \mathrm{t} / \mathrm{ha}$ & 5.828 & 8.916 & 7.267 & $7.337 \mathrm{a}$ \\
$2 \mathrm{t} / \mathrm{ha}$ & 10.015 & 7.983 & 8.113 & $8.704 \mathrm{a}$ \\
$3 \mathrm{t} / \mathrm{ha}$ & 7.233 & 8.493 & 7.334 & $7.687 \mathrm{a}$ \\
\hline Rerata & $7.591 \mathrm{a}$ & $7.683 \mathrm{a}$ & $6.958 \mathrm{a}$ & $(-)$ \\
\hline
\end{tabular}

Keterangan: Angka pada kolom dan baris diikuti huruf sama menunjukkan tidak berbeda nyata pada tingkat $\alpha .5 \%$ menurut uji DMRT. (-): Tidak terjadi interaksi antar faktor.

\subsection{Bintil Akar}

Hasil sidik ragam (Anova) menunjukkan bahwa ada interaksi antara pemberian takaran guano $2 \mathrm{t} / \mathrm{ha}$ dan konsentrasi teh kompos untuk tanaman kacang hijau pada pengamatan bintil akar yang besar dan kecil dibanding takaran 2,3 t/ha dan kontrol sedangkan bintil akar efektif yang terbanyak terdapat pada $3 \mathrm{t} / \mathrm{ha}$ dibanding takaran $1 \mathrm{t} / \mathrm{ha}, 2 \mathrm{t} / \mathrm{ha}$ dan kontrol namun bintil akar yang tidak efektif yang terendah terdapat pada kontrol.

Pemberian teh kompos 1:5 memberikan pengaruh yang nyata sedangkan bintil akar yang kecil tertinggi pada 1:10 namun bintil akar yang efektif terbanyak pada konsentrasi 1:10, sedangkan bintil akar yang tidak efektif jumlah paling sedikit pada 1:5. 
Tabel 9. Bintil Akar

\begin{tabular}{|c|c|c|c|c|c|}
\hline \multirow{2}{*}{ Bintil Akar } & \multirow{2}{*}{$\begin{array}{c}\text { Takaran } \\
\text { Guano }\end{array}$} & \multicolumn{3}{|c|}{ Konsentrasi Teh Kompos } & \multirow{2}{*}{ Rerata } \\
\hline & & Kontrol & $1: 5$ & $1: 10$ & \\
\hline \multirow{5}{*}{ Besar } & Kontrol & $17.00 \mathrm{c}$ & $21.75 \mathrm{bc}$ & $24.88 \mathrm{bc}$ & 21.21 \\
\hline & $1 \mathrm{t} / \mathrm{ha}$ & $38.50 \mathrm{ab}$ & $39.88 \mathrm{ab}$ & $39.75 \mathrm{ab}$ & 39.38 \\
\hline & $2 \mathrm{t} / \mathrm{ha}$ & $33.50 \mathrm{abc}$ & $33.50 \mathrm{abc}$ & $34.38 \mathrm{abc}$ & 33.79 \\
\hline & $3 \mathrm{t} / \mathrm{ha}$ & $30.25 \mathrm{abc}$ & $48.13 \mathrm{a}$ & $40.50 \mathrm{ab}$ & 39.63 \\
\hline & Rerata & 29.81 & 35.81 & 34.88 & $(+)$ \\
\hline \multirow{5}{*}{ Kecil } & Kontrol & $34.75 \mathrm{ab}$ & $26.00 \mathrm{~b}$ & $32.50 \mathrm{ab}$ & 31.08 \\
\hline & $1 \mathrm{t} / \mathrm{ha}$ & $44.38 \mathrm{ab}$ & $33.00 \mathrm{ab}$ & $51.00 \mathrm{ab}$ & 42.79 \\
\hline & $2 \mathrm{t} / \mathrm{ha}$ & $60.00 \mathrm{a}$ & $41.38 \mathrm{ab}$ & $42.50 \mathrm{ab}$ & 47.96 \\
\hline & $3 \mathrm{t} / \mathrm{ha}$ & $48.75 \mathrm{ab}$ & $45.13 \mathrm{ab}$ & $58.88 \mathrm{a}$ & 50.92 \\
\hline & Rerata & 46.97 & 36.38 & 46.22 & $(+)$ \\
\hline \multirow{5}{*}{ Efektif } & Kontrol & $25.75 b$ & $27.13 \mathrm{~b}$ & $33.00 \mathrm{ab}$ & 28.63 \\
\hline & $1 \mathrm{t} / \mathrm{ha}$ & $52.00 \mathrm{a}$ & $38.75 \mathrm{ab}$ & $52.75 \mathrm{a}$ & 47.83 \\
\hline & $2 \mathrm{t} / \mathrm{ha}$ & $49.88 \mathrm{a}$ & $44.38 \mathrm{ab}$ & $37.25 \mathrm{ab}$ & 43.83 \\
\hline & $3 \mathrm{t} / \mathrm{ha}$ & $39.38 \mathrm{ab}$ & $54.00 \mathrm{a}$ & $54.63 \mathrm{a}$ & 49.33 \\
\hline & Rerata & 41.75 & 41.06 & 44.41 & $(+)$ \\
\hline \multirow{5}{*}{$\begin{array}{l}\text { Tidak } \\
\text { Efektif }\end{array}$} & Kontrol & $28.25 \mathrm{~b}$ & $19.38 \mathrm{ab}$ & $24.38 \mathrm{ab}$ & 24.00 \\
\hline & $1 \mathrm{t} / \mathrm{ha}$ & $31.50 \mathrm{ab}$ & $34.13 \mathrm{ab}$ & $37.38 \mathrm{ab}$ & 34.33 \\
\hline & $2 \mathrm{t} / \mathrm{ha}$ & $44.00 \mathrm{a}$ & $32.13 \mathrm{ab}$ & $38.63 \mathrm{ab}$ & 38.25 \\
\hline & $3 \mathrm{t} / \mathrm{ha}$ & $39.00 \mathrm{a}$ & $39.25 \mathrm{ab}$ & $42.38 \mathrm{ab}$ & 40.21 \\
\hline & Rerata & 35.69 & 31.22 & 35.69 & $(+)$ \\
\hline
\end{tabular}

Keterangan: Angka pada kolom dan baris diikuti huruf sama menunjukkan tidak berbeda nyata pada tingkat $\alpha 5 \%$ menurut uji DMRT. (+): Terjadi interaksi antar faktor.

\subsection{Karat Daun}

Hasil sidik ragam (Anova) menunjukkan bahwa tidak ada interaksi antara pemberian takaran guano dan konsentrasi teh kompos untuk tanaman kacang hijau pada pengamatan karat daun, namun pemberian takaran guano $0 \mathrm{t} / \mathrm{ha}$ menunjukkan beda nyata dibanding takaran $1 \mathrm{t} / \mathrm{ha}, 2 \mathrm{t} / \mathrm{ha}$ dan $3 \mathrm{t} / \mathrm{ha}$. Pemberian teh kompos tidak memberikan pengaruh yang nyata namun pada konsentrasi 1:10 mengurangkan serangan karang daun dibanding 1:5 dan kontrol.

\section{Tabel 10. Karat Daun}

\begin{tabular}{ccccc}
\hline \multirow{2}{*}{ Takaran Guano } & \multicolumn{3}{c}{ Konsentrasi Teh Kompos } & \multirow{2}{*}{ Rerata } \\
\cline { 2 - 4 } & Kontrol & $1: 5$ & $1: 10$ & \\
\hline Kontrol & 6.593 & 5.747 & 5.297 & $5.879 \mathrm{a}$ \\
$1 \mathrm{t} / \mathrm{ha}$ & 6.520 & 9.912 & 7.541 & $7.991 \mathrm{a}$ \\
$2 \mathrm{t} / \mathrm{ha}$ & 9.832 & 8.356 & 8.216 & $8.802 \mathrm{a}$ \\
$3 \mathrm{t} / \mathrm{ha}$ & 9.308 & 8.669 & 9.083 & $9.020 \mathrm{a}$ \\
\hline Rerata & $8.063 \mathrm{a}$ & $8.171 \mathrm{a}$ & $7.534 \mathrm{a}$ & $(-)$ \\
\hline
\end{tabular}

Keterangan: Angka pada kolom dan baris diikuti huruf sama menunjukkan tidak berbeda nyata pad: tingkat $\alpha 5 \%$ menurut uji DMRT. (-): Tidak terjadi interaksi antar faktor.

\subsection{Jumlah Polong}

Hasil sidik ragam (Anova) menunjukkan bahwa ada interaksi antara pemberian takaran guano dan konsentrasi teh kompos untuk tanaman kacang hijau pada pengamatan jumlah polong, namun pemberian guano 1 t/ha menunjukkan beda nyata dibanding takaran $1 \mathrm{t} / \mathrm{ha}, 3 \mathrm{t} / \mathrm{ha}$ dan kontrol. demikian pemberian teh kompos tidak memberikan pengaruh yang nyata namun pada konsentrasi 1:10 meningkatkan jumlah polong dibanding 1:5 dan kontrol.

$\underline{\text { Tabel 11. Jumlah Polong }}$

\begin{tabular}{cllll}
\hline \multirow{2}{*}{ Takaran Guano } & \multicolumn{3}{c}{ Konsentrasi Teh Kompos } & \multirow{2}{*}{ Rerata } \\
\cline { 2 - 4 } & \multicolumn{1}{|c}{ Kontrol } & \multicolumn{1}{c}{$1: 5$} & \multicolumn{1}{c}{$1: 10$} & \\
\hline Kontrol & $14.70 \mathrm{~d}$ & $24.95 \mathrm{abc}$ & $24.60 \mathrm{abc}$ & 21.42 \\
$1 \mathrm{t} / \mathrm{ha}$ & $22.75 \mathrm{abcd}$ & $17.55 \mathrm{dc}$ & $28.05 \mathrm{ab}$ & 22.78 \\
$2 \mathrm{t} / \mathrm{ha}$ & $31.50 \mathrm{a}$ & $15.85 \mathrm{dc}$ & $15.50 \mathrm{dc}$ & 20.95 \\
$3 \mathrm{t} / \mathrm{ha}$ & $21.30 \mathrm{bcd}$ & $19.49 \mathrm{bcd}$ & $24.20 \mathrm{abc}$ & 21.66 \\
\hline Rerata & 22.56 & 19.46 & 23.09 & $(+)$ \\
\hline
\end{tabular}

Keterangan: Angka pada kolom dan baris diikuti huruf sama menunjukkan tidak berbeda nyata pada tingkat $\alpha 5 \%$ menurut uji DMRT. (+): Terjadi interaksi antar faktor.

\subsection{Panjang Polong}

Hasil sidik ragam (Anova) menunjukkan bahwa ada interaksi antara pemberian takaran guano dan konsentrasi teh kompos untuk tanaman kacang hijau pada pengamatan panjang polong, namun pemberian guano 1 t/ha menunjukkan beda nyata dibanding takaran 2 t/ha, 3 t/ha dan kontrol. Pemberian teh kompos tidak memberikan pengaruh yang nyata namun pada konsentrasi 1: 10 meningkatkan panjang polong dibanding 1:5 dan kontrol.

Tabel 12. Panjang Polong (cm)

\begin{tabular}{ccccc}
\hline \multirow{2}{*}{ Takaran Guano } & \multicolumn{3}{c}{ Konsentrasi Teh Kompos } & \multirow{2}{*}{ Rerata } \\
\cline { 2 - 4 } & Kontrol & $1: 5$ & $1: 10$ & \\
\hline Kontrol & 12.20 & 12.73 & 13.98 & 12.97 \\
$1 \mathrm{t} / \mathrm{ha}$ & 13.49 & 12.41 & $14.60 \mathrm{a}$ & 13.50 \\
$2 \mathrm{t} / \mathrm{ha}$ & 12.94 & 13.40 & $11.86 \mathrm{~b}$ & 12.73 \\
$3 \mathrm{t} / \mathrm{ha}$ & $12.12 \mathrm{~b}$ & 14.05 & 13.11 & 13.10 \\
\hline Rerata & 12.69 & 13.15 & 13.39 & $(+)$ \\
\hline
\end{tabular}

Keterangan: Angka pada kolom dan baris diikuti huruf sama menunjukkan tidak berbeda nyata pada tingkat $\alpha 5 \%$ menurut uji DMRT. (+): Terjadi interaksi antar faktor.

\subsection{Jumlah Biji Per Polong}

Hasil sidik ragam (Anova) menunjukkan bahwa ada interaksi antara pemberian takaran guano dan konsentrasi teh kompos untuk tanaman kacang hijau pada pengamatan jumlah biji/polong, namun pemberian guano 1 t/ha menunjukkan beda nyata dibanding takaran 2 t/ha, 3 t/ha dan kontrol. Pemberian teh kompos tidak memberikan pengaruh yang nyata namun pada konsentrasi 1:5 meningkatkan jumlah biji per polong dibanding 1:10 dan kontrol.

Tabel 13. Jumlah Biji Per Polong

\begin{tabular}{ccccc}
\hline \multirow{2}{*}{ Takaran Guano } & \multicolumn{2}{c}{ Konsentrasi Teh Kompos } & \multirow{2}{*}{ Rerata } \\
\cline { 2 - 4 } & Kontrol & 1.5 & $1: 10$ & \\
\hline Kontrol & $7.40 \mathrm{ab}$ & $8.58 \mathrm{ab}$ & $7.97 \mathrm{ab}$ & 8.71 \\
$1 \mathrm{t} / \mathrm{ha}$ & $9.58 \mathrm{~b}$ & $7.54 \mathrm{ab}$ & $8.15 \mathrm{ab}$ & 7.70 \\
$2 \mathrm{t} / \mathrm{ha}$ & $7.26 \mathrm{ab}$ & $9.09 \mathrm{ab}$ & $7.64 \mathrm{ab}$ & 8.00 \\
$3 \mathrm{t} / \mathrm{ha}$ & $6.65 \mathrm{~b}$ & $7.94 \mathrm{ab}$ & $7.22 \mathrm{ab}$ & 7.27 \\
\hline Rerata & 7.72 & 8.29 & 7.74 & $(+)$ \\
\hline Keterangan & Angka pada & kolom & &
\end{tabular}

Keterangan: Angka pada kolom dan baris diikuti huruf sama menunjukkan tidak berbeda nyata pada tingkat $\alpha 5 \%$ menurut uji DMRT. (+): Terjadi interaksi antar faktor.

\subsection{Berat Biji Tanaman}

Hasil sidik ragam (Anova) menunjukkan bahwa ada interaksi antara pemberian takaran guano 1t/ha dan konsentrasi teh kompos untuk tanaman kacang hijau pada pengamatan berat biji tanaman, dibanding takaran $2 \mathrm{t} / \mathrm{ha}, 3$ t/ha dan kontrol. Sedangkan pemberian teh kompos tidak memberikan pengaruh yang nyata namun pada konsentrasi 1:5 meningkatkan berat biji tanaman dibanding 1:10 dan kontrol.

\section{Tabel 14. Berat Biji Tanaman (gr)}

\begin{tabular}{cllll}
\hline \multirow{2}{*}{ Takaran Guano } & \multicolumn{3}{c}{ Konsentrasi Teh Kompos } & \multirow{2}{*}{ Rerata } \\
\cline { 2 - 4 } & \multicolumn{1}{c}{ Kontrol } & \multicolumn{1}{c}{$1: 5$} & \multicolumn{1}{c}{$1: 10$} & \\
\hline Kontrol & $14.81 \mathrm{c}$ & $33.09 \mathrm{abc}$ & $20.52 \mathrm{ca}$ & 22.80 \\
$1 \mathrm{t} / \mathrm{ha}$ & $43.28 \mathrm{ab}$ & $52.73 \mathrm{a}$ & $46.44 \mathrm{a}$ & 47.48 \\
$2 \mathrm{t} / \mathrm{ha}$ & $47.58 \mathrm{a}$ & $49.88 \mathrm{a}$ & $33.16 \mathrm{abc}$ & 43.54 \\
$3 \mathrm{t} / \mathrm{ha}$ & $49.03 \mathrm{a}$ & $25.87 \mathrm{bc}$ & $51.54 \mathrm{a}$ & 42.15 \\
\hline Rerata & 38.68 & 40.39 & 37.91 & $(+)$ \\
\hline
\end{tabular}

Keterangan: Angka pada kolom dan baris diikuti huruf sama menunjukkan tidak berbeda nyata pada tingkat $\alpha 5 \%$ menurut uji DMRT. (+): Terjadi interaksi antar faktor.

\subsection{Berat Biji Per Petak}

Hasil sidik ragam (Anova) menunjukkan bahwa ada interaksi antara pemberian takaran guano $2 \mathrm{t} / \mathrm{ha}$ dan konsentrasi teh kompos untuk tanaman kacang hijau pada pengamatan berat biji per petak (t/ha), dibanding takaran 1 $\mathrm{t} / \mathrm{ha}, 3 \mathrm{t} / \mathrm{ha}$ dan kontrol. sedangkan pemberian teh kompos tidak memberikan pengaruh yang nyata namun pada konsentrasi 1:5 meningkatkan berat biji per petak (t/ha) dibanding 1:10 dan kontrol.

\section{Tabel 15. Berat Biji Per Petak (t/ha)}

\begin{tabular}{|c|c|c|c|c|}
\hline \multirow{2}{*}{ Takaran Guano } & \multicolumn{3}{|c|}{ Konsentrasi Teh Kompos } & \multirow{2}{*}{ Rerata } \\
\hline & Kontrol & $1: 5$ & $1: 10$ & \\
\hline Kontrol & $0.28 \mathrm{c}$ & $0.52 \mathrm{abc}$ & $0.59 \mathrm{c}$ & 0.46 \\
\hline $1 \mathrm{t} / \mathrm{ha}$ & $0.75 \mathrm{ab}$ & $1.07 \mathrm{a}$ & $0.78 \mathrm{a}$ & 0.87 \\
\hline $2 \mathrm{t} / \mathrm{ha}$ & $1.02 \mathrm{a}$ & $0.93 \mathrm{a}$ & $0.99 \mathrm{abc}$ & 0.98 \\
\hline $3 \mathrm{t} / \mathrm{ha}$ & $0.76 \mathrm{a}$ & $0.85 \mathrm{bc}$ & $0.93 \mathrm{a}$ & 0.85 \\
\hline Rerata & 0.71 & 0.84 & 0.82 & $(+)$ \\
\hline
\end{tabular}
tingkat $\alpha 5 \%$ menurut uji DMRT. (+): Terjadi interaksi antar faktor.

\subsection{Berat 100 Biji}

Hasil sidik ragam (Anova) menunjukkan bahwa ada interaksi antara pemberian takaran guano dan konsentrasi teh kompos untuk tanaman kacang hijau pada pengamatan berat 100 biji, namun pemberian guano $3 \mathrm{t} / \mathrm{ha}$ menunjukkan beda nyata dibanding takaran $1 \mathrm{t} / \mathrm{ha}, 2 \mathrm{t} / \mathrm{ha}$ dan kontrol. Demikian pemberian teh kompos tidak memberikan pengaruh yang nyata namun pada konsentrasi 1:5 meningkatkan berat 100 biji dibanding 1:10 dan kontrol.

Tabel 16. Berat 100 Biji (gr)

\begin{tabular}{cllll}
\multirow{2}{*}{ Takaran Guano } & \multicolumn{2}{c}{ Konsentrasi Teh Kompos } & \multirow{2}{*}{ Rerata } \\
\cline { 2 - 4 } & Kontrol & $1: 5$ & $1: 10$ & \\
\hline Kontrol & $6.55 \mathrm{~d}$ & $6.81 \mathrm{dc}$ & $6.49 \mathrm{bcd}$ & 6.61 \\
$1 \mathrm{t} / \mathrm{ha}$ & $6.65 \mathrm{abc}$ & $6.69 \mathrm{a}$ & $6.60 \mathrm{abc}$ & 6.65 \\
$2 \mathrm{t} / \mathrm{ha}$ & $6.85 \mathrm{ab}$ & $6.69 \mathrm{abc}$ & $6.89 \mathrm{ab}$ & 6.81 \\
$3 \mathrm{t} / \mathrm{ha}$ & $6.83 \mathrm{abc}$ & $7.19 \mathrm{abc}$ & $6.96 \mathrm{abc}$ & 6.99 \\
\hline Rerata & 6.72 & 6.85 & 6.73 & $(+)$ \\
\hline Keterangan: Angka pada kolom dan baris diikuti huruf sama menunjukkan tidak berbeda nyata
\end{tabular}
pada tingkat $\alpha .5 \%$ menurut uji DMRT. (+): Terjadi interaksi antar faktor.

\subsection{Berat Kering Berangkasan}

Hasil sidik ragam (Anova) menunjukkan bahwa ada interaksi antara pemberian takaran guano 2 t/ha dan konsentrasi teh kompos untuk tanaman kacang hijau pada pengamatan berat kering berangkasan, dibanding takaran 1 
t/ha, 3 t/ha dan kontrol. sedangkan pemberian teh kompos tidak memberikan pengaruh yang nyata namun pada konsentrasi 1:5 meningkatkan berat kering berangkasan dibanding 1:10 dan kontrol.

Tabel 17. Berat Kering Berangkasan (gr)

\begin{tabular}{|c|c|c|c|c|}
\hline \multirow{2}{*}{ Takaran Guano } & \multicolumn{3}{|c|}{ Konsentrasi Teh Kompos } & \multirow{2}{*}{ Rerata } \\
\hline & Kontrol & $1: 5$ & $1: 10$ & \\
\hline Kontrol & $450.00 \mathrm{ab}$ & $490.50 \mathrm{ab}$ & $325.00 \mathrm{ab}$ & 421.83 \\
\hline $1 \mathrm{t} / \mathrm{ha}$ & $625.00 \mathrm{ab}$ & $700.00 \mathrm{ab}$ & $510.00 \mathrm{ab}$ & 611.67 \\
\hline $2 \mathrm{t} / \mathrm{ha}$ & $695.00 \mathrm{ab}$ & $835.00 \mathrm{ab}$ & $842.50 \mathrm{ab}$ & 790.83 \\
\hline $3 \mathrm{t} / \mathrm{ha}$ & $557.50 \mathrm{ab}$ & $805.00 \mathrm{a}$ & $637.50 \mathrm{ab}$ & 666.67 \\
\hline Rerata & 581.88 & 707.63 & 578.75 & $(+)$ \\
\hline
\end{tabular}

Keterangan: Angka pada kolom dan baris diikuti huruf sama menunjukkan tidak berbeda nyata pada tingkat $\alpha 5 \%$ menurut uji DMRT. (+): Terjadi interaksi antar faktor.

\subsection{Indeks Panen}

Hasil sidik ragam (Anova) menunjukkan bahwa ada interaksi antara pemberian takaran $3 \mathrm{t} /$ ha guano dan konsentrasi teh kompos 1:5 memiliki nilai indeks panen yang lebih tinggi untuk tanaman kacang hijau.

Tabel 18. Indeks Panen

\begin{tabular}{cllll}
\hline \multirow{2}{*}{ Takaran Guano } & \multicolumn{3}{c}{ Konsentrasi Teh Kompos } & \multirow{2}{*}{ Rerata } \\
\cline { 2 - 3 } & \multicolumn{1}{c}{ Kontrol } & \multicolumn{1}{c}{$1: 5$} & \multicolumn{1}{c}{$1: 10$} & \\
\hline Kontrol & $18.84 \mathrm{ab}$ & $30.12 \mathrm{ab}$ & $36.18 \mathrm{~b}$ & 28.38 \\
$1 \mathrm{t} / \mathrm{ha}$ & $25.48 \mathrm{ab}$ & $32.95 \mathrm{ab}$ & $33.85 \mathrm{ab}$ & 30.76 \\
$2 \mathrm{t} / \mathrm{ha}$ & $30.95 \mathrm{ab}$ & $29.50 \mathrm{a}$ & $30.95 \mathrm{a}$ & 30.46 \\
$3 \mathrm{t} / \mathrm{ha}$ & $28.10 \mathrm{ab}$ & $29.47 \mathrm{ab}$ & $28.23 \mathrm{ab}$ & 28.60 \\
\hline Rerata & 25.84 & 30.51 & 32.30 & $(+)$ \\
\hline
\end{tabular}

Keterangan: Angka pada kolom dan baris diikuti huruf sama menunjukkan tidak berbeda nyata pada tingkat $\alpha 5 \%$ menurut uji DMRT. (+): Terjadi interaksi antar faktor.

\subsection{Pembahasan}

Dari setiap parameter pertumbuhan yang diamati kacang hijau yang diberi guano pertumbuhannya jauh lebih baik dibandingkan dengan kacang hijau yang tidak diberi guano (kontrol). Hasil penelitian menunjukkan bahwa kacang hijau yang diberi guano dengan takaran 2 t/ha dapat meningkatkan pertumbuhan tanaman kacang hijau yang dapat diekspresikan dalam bentuk tinggi tanaman, diameter batang, panjang akar,luas daun dan hasil (panjang polong, berat biji/petak, berat segar brangkasan) dibandingkan $1 \mathrm{t} / \mathrm{ha}, 3 \mathrm{t} / \mathrm{ha}$ dan kontrol.

Pertumbuhan tanaman yang baik tersebut didukung oleh kondisi lingkungan yang optimal, ditunjukkan pada parameter suhu tanah terendah pada perlakuan 2 t/ha. Selain itu dengan pemberian teh kompos pada konsentrasi 1:5 dapat mengendalikan serangan penyakit karat daun sehingga pertumbuhan tanaman lebih sehat dan pada akhirnya diperoleh hasil kacang hijau yang lebih tinggi, yakni sebanyak 0.98 t/ha. Hasil ini masih jauh dari produktivitas kacang hijau di Kabupaten TTU tetapi mendekati hasil penelitian terdahulu yang dilakukan oleh (Manehat et al., 2016) yang menggunakan kacang hijau varietas Vima 1 dengan hasil 1,91 t/ha.

\section{Simpulan}

Pemberian pupuk guano 2 t/ha meningkatkan pertumbuhan tanaman kacang hijau, diameter batang, panjang akar, luas daun dan hasil (jumlah biji per polong, berat biji per petak, berat segar berangkasan). Teh kompos dengan konsentrasi 1:5 yang diaplikasikan pada tanaman kacang hijau dapat mengurangi serangan karat daun paling terendah dibandingkan 1:10 dan kontrol. Pertumbuhan dan hasil kacang hijau yang paling tinggi diperoleh dari aplikasi guano 2 t/ha dikombinasikan dengan konsentrasi teh kompos 1:5.

\section{Pustaka}

BPS Kab. TTU 2015. Timor Tengah Utara dalam Angka 2015. Kefamenanu: Badan Pusat Statistik Kabupaten TTU.

Bria, D. 2016. Pengaruh Jenis dan Konsentrasi Teh Kompos Terhadap Pertumbuhan dan Hasil Bayam Merah (Alternanthera amoena, Voss). Savana Cendana, 1(03): 108-111.

Gomez, K.A. \& Gomez, A.A. 1984. Statistical Procedures for Agricultural Research. New York: John Wiley \& Sons.

Manehat, S.J., Taolin, R.I. \& Lelang, M.A. 2016. Pengaruh Jenis dan Dosis Pupuk Kandang Terhadap Pertumbuhan dan Hasil Kacang Hijau (Vigna radiata, L.). Savana Cendana, 1(01): 24-30.

Nadiah, A. 2012. Petujuk Teknis Pengembangan Teknologi Teh Kompos Untuk Pengendalian OPT Perkebunan. Surabaya: Balai Besar Perbenihan dan Proteksi Tanaman Perkebunan.

Taek, R. 2016. Pengaruh Takaran Arang Sekam dan Guano Terhadap Pertumbuhan dan Hasil Kacang Hijau (Vigna radiata, L.). Savana Cendana, 1(04): 121-124.

Yugi, A. \& Harjoso, T. 2012. Karakter Hasil Biji Kacang Hijau pada Kondisi Pemupukan P dan Intensitas Penyiangan Berbeda. J. Agrivigor, 137-143. 